\title{
BRAND VALUE OF PUBLIC UNIVERSITIES IN HO CHI MINH CITY, VIETNAM
}

\author{
Ai Tran Huu \\ Nguyen Le Thi Minh \\ My Phan Thi Chieu \\ Van Hien University, Ho Chi Minh City, Vietnam
}

The brand and brand building are extremely important and have a long-term meaning for all organizations. Concerns about branding have first started to rise in the field of tangible products but then gradually shifted to the services sector. The intangible nature of a service makes consumers rely on brand elements more when assessing the quality and deciding to buy. Many types of services need to rely on brand reputation so that to attract customers, for example, healthcare services, counseling, and education. The influencing factors here are the factors that together make up brand value according to the model by Aaker (1991), which includes brand awareness, perceived quality, brand association, and brand loyalty.

Keywords: brand; brand value; services sector; university; Ho Chi Minh City; Vietnam

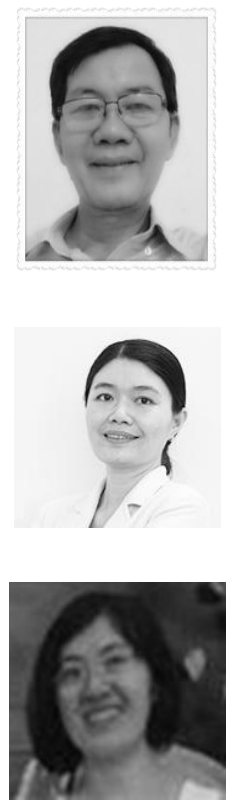

\begin{abstract}
Ai Tran Huu
$\mathrm{PhD}$, lecturer of Faculty of Economics, Van Hien University, Ho Chi Minh City, Vietnam

Research interests - markets of agricultural products, SMEs functioning and government support, organic food markets, ecological economics, environmental issues of economic development and corporate social responsibility Published more than 60 papers in International journals, member of editorial board of International journals

E-mail: aith@vhu.edu.vn

Nguyen Le Thị Minh

MBA, Lecturer of Faculty of Economics, Van Hien University, Ho Chi Minh City, Vietnam Research interests: SMEs functioning and government support, consumer behavior, innovative products markets and finances. Published more than 20 papers in International journals.

E-mail: nguyenltm@vhu.edu.vn
\end{abstract}

\section{My Pham Thi Chieu}

MBA, Lecturer of Faculty of Economics, Van Hien University, Ho Chi Minh City, Vietnam Research interests: SMEs functioning and government support, consumer behavior, innovative products markets and finances.

Published more than 20 papers in International journals.

E-mail: myptc@vhu.edu.vn 


\section{BRAND VALUE OF PUBLIC UNIVERSITIES}

\section{Introduction}

University education is a special type of service with its own specific features: high intangible content, direct impact on human minds, difficulties with assessing quality, based on prestige, conditions of use, requires direct participation from learners, must meet the requirements of both learners and their future employers. These characteristics make the training institutions' brands important when future learners are choosing and evaluating the institutions.

Over the past 15 years, the number of university institutions in Vietnam has increased rapidly. This increase in the number of universities has made the level of competition between higher education institutions stronger than never before. The new policies of the Government and the Ministry of Education and Training to improve the quality of the university education system and strengthen the autonomy of universities make the issue of branding even more necessary. University branding has been an important highlight in marketing communications as it attracts learners and brings financial resources to schools. From the point of view of customers (learners, employers and the society in general) are always interested and learn thoroughly about training activities as well as university brands since they are trying to make the right decisions regarding today's students as future workers. At this, the ability of future graduates to work seems to be the key parameter.

When it comes to university training, people often refer to Harvard, MIT, Cambridge or Oxford as the "monuments" in this field of services. The brand of a university can be also seen as the school's trading name, associated with its identity, prestige and image which together are making a deep imprint on learners, partners, employers. Brand also distinguishes one school from all other schools present at the market. In other words, the brand of a school is the perception in the minds of learners, parents, staff (primarily lecturers), cooperation partners and future employer of the school graduates.

The competitive pressure on domestic universities also comes from foreign universities. First of all, it is a group of foreign universities that invest in opening direct trainings or training associations in Vietnam such as RMIT or La Trobe University. The country has 273 training affiliated programs with foreign elements being licensed. That is not to mention, it is difficult to determine the scope of the market and competitors in the field of higher education in Vietnam when the trend of studying abroad is increasing all the time. In addition, the process of getting more of financial autonomy for public universities promises to be another test for their brand value.

\section{Competition between public universities}

Most public universities have a long history, often several campuses, stable facilities, and stable presence of faculty members.

Today's public universities in Vietnam can be divided into two groups: a group specializing in economic and business training and the other group specializing in other disciplines (engineering, technology, social sciences and humanities, foreign languages and so on).

However, today many universities that are officially not in the economics \& business administration group, are still opening branches and enrolling students in Economics and Business Administration. According to the Ministry of Education and Training, among 416 universities and colleges in total, there are 248 schools (thus accounting for 59.6\%) with 
enrollment in Economics and Business Administration. Only 38\% of the total enrollment quota cover all other sectors (Bao Nam, 2013). Because most public universities today have such enrollment statistics, the level of competition between them is getting even more dangerous due to imbalance.

\section{Competition between public and non-public universities}

According to the Ministry of Education and Training, in the period of 2010-2018, the number of non-public schools has increased from 50 to 90 , accounting for $26.6 \%$ of the total number of universities. The number of non-public students back in 2018 was 244,367, accounting for $16,01 \%$ of the total number of students in all universities. Thus, non-public schools are accounting for more than $1 / 4$ of all schools and at the same time, nearly 1/8 from the total number of students in the country.

Although there are many inadequacies in facilities, classrooms, teachers and training quality, the emergence of non-public universities also creates certain competitive pressure on public schools. The entrance standards of public schools are changing due to this pressure. Also, this newer competition is forcing public schools to renew their training programs and improve their quality.

\section{Competition between domestic and foreign universities}

The emergence of foreign universities also creates certain competitive pressure on domestic universities. Although tuition fees are high, foreign universities have their own competitive advantages: (1) international brand reputation of the source university; (2) there is no limit on tuition fees such as with domestic training institutions; (3) foreign universities usually have a separate enrollment mechanism and they can enroll students several times during one calendar year; (4) foreign universities do not depend on industry constraints and/or training program requirements of the Ministry of Education in terms of their curriculum framework.

Currently, in Vietnam, there are $2100 \%$ foreign-owned universities that have been active and have graduated students already. These are Royal Melbourne Institute of Technology Vietnam and British University Vietnam.

\section{Theoretical Background Of The Study}

According to the American Marketing Associations dictionary (2015), brand is a name, term, design, symbol or any other characteristic that identifies a seller's tangible product or service and distinguishes them from the products and services of other sellers.

However, the above definition of brand is rather limited since it is not expressing the emotional attitude of consumers to a brand (Keller 2013). Brands also bring many benefits to consumers. Thus, brand value is the value brought by the brand name to the product (Lassar et al., 1995). Brand value is consumer perception of the overall superiority of a product bearing that brand name as compared to other brands (Lassar et al., 1995).

Brand value is the different effect of a brand name on consumer responses to marketing stimuli resulting from brand knowledge (Keller, 1993). Keller (2013, p. 41) believes that high brand value will bring the following benefits to the seller: (1) Product features' awareness will be more positive, (2) Higher level of loyalty, (3) Less negative effects from 


\section{BRAND VALUE OF PUBLIC UNIVERSITIES}

competitors' marketing activities, (4) Higher profits, (5) Demand curve is less elastic when price increases, thus, there are opportunities to expand the brand.

David Aaker (1991) has been one of the first scholars to build a model of brand value, its components and brand equity dimensions. He thinks that this multi-component concept consists of the following five main components: brand awareness, perceived quality, brand associations, brand loyalty, other proprietary assets.

\section{Brand awareness}

D. Aaker (1991, p. 61) defines brand awareness as "the ability of a potential buyer to get back and remember a brand in a certain product category". Brand awareness provides brand owners with the following four main benefits (Aaker, 1991): (1) the source of brand associations; (2) creating acquaintance with the brand; (3) actual commitment; and (4) creating opportunities for customers to consider and choose to buy the product.

\section{Brand association}

Brand association is defined as "anything in the minds of customers that is associated with brand names" (Aaker, 1991: 109). There are many different types and classifications of brand associations. Associating the brand gives the owner of a trademark the following benefits: (1) it stimulates processing and retrieval of information in the minds of customers; (2) it creates differences in brand positioning; (3) it creates additional reasons to buy this product specifically; (4) it creates positive attitude towards the brand; and (5) finally, it creates the basis for further brand extension. If a brand owns more and more positive brand associations and the strength of brand associations is getting higher, then this brand would have higher brand value (Aaker, 1991; Keller, 1993).

\section{Perceived quality}

Perceived quality is defined as customer perceptions of the overall quality or overall superiority of tangible products or services in comparison with other products. High perceived quality has many values or benefits for producers: (1) providing reasons for buying; (2) is the factor that differentiates and locates products and/or organizations in the minds of customers; (3) provides additional interest for the members of the distribution channel; (4) higher valuation overall, and (5) facilitation of brand expansion.

\section{Brand loyalty}

Brand loyalty shows the degree of buyer's attachment to the brand. This loyalty includes the behavioral aspect (expressed in the frequency of repeated purchases of the same product/service) or the attitudinal aspect (trust, commitment to engagement or introductions to others). Brand loyalty has many benefits for businesses: (1) it guarantees stable sales; (2) it reduces costs related to attraction of new customers; (3) it helps businesses promote themselves through the word of mouth; (4) it gives businesses time to respond adequately to competition (Aaker, 1991).

\section{Research hypotheses}

A brand needs to be known, only then consumers can evaluate it, and only when known, a new brand can be valuable in consumers' minds. If brand awareness is low, brand's 
value will be very low (Aaker, 1991; Keller, 1993; Buil et al., 2013; Keller, 2013). Therefore, we are formulating the first hypothesis as follows:

H1: Brand awareness has a positive impact on the brand value of the school.

Perceived quality acts as a foundation for building brand value of growth. If the brand has high level of awareness, but its perceived quality is low -- it brand value will go down quickly. Thus, in addition to making the brand highly recognizable, organizations need to take care of high perceived quality of the brand (Aaker, 1991; Keller, 1993; Yoo \& Donthu, 2001; Buil et al., 2013). Therefore, our second hypothesis in relation to the universities in question can be formulated as follows:

$\mathrm{H} 2$ : Perceived quality positively impacts the brand value of the school.

Wood (2000) stated that brand value is essentially a collection of associations related to brand names. Aaker (1991) and Keller (1993) also argued that brand association is an important component of a positive response and brand differentiation. If a brand owns more and more positive brand associations, its brand value will be greater (Wood, 2000; Aaker, 1991; Keller, 1993; Yoo \& Donthu, 2001; Buil et al., 2013). Therefore, our third hypothesis can be formulated as follows:

H3: Brand association has a positive effect on the brand value of the school.

If a brand has many loyal customers, then this brand will have many opportunities to sustain and increase revenues, reduce costs and increase profit margins, meaning that the brand's financial value will be sufficiently high (Kotler \& Keller, 2012). High levels of loyalty also show that customers trust the brand and consider this particular brand as something more valuable than other similar brands (Aaker, 1991; Keller, 1993; Yoo \& Donthu, 2001; Buil et al., 2013; Keller, 2013). Therefore, it can be hypothesized that:

$\mathrm{H} 4$ : Brand loyalty has a positive impact on the brand value of the school.

Only after knowing the brand its consumers can feel the quality of the product with that brand name (Kaker, 1991). Kapferer (2008, p. 21) used the survey results on 9,739 consumers and 507 brands and found that brand awareness has a positive correlation coefficient (+0.43) with perceived quality. Build et al. (2013) also confirmed the positive (same-way) impact of brand awareness on perceived quality. Therefore, the following hypothesis may be stated about the effect of brand awareness on perceived quality:

H5: Brand awareness has a positive effect on perceived quality.

Build et al. (2013) also demonstrated, using survey data, that brand awareness has a (mutually) positive effect on the perception of values, brand personality, and organizational associations. These are key ingredients in brand association. Therefore, the following hypothesis can be formulated about the effect of brand awareness on brand associations:

H6: Brand awareness has a positive impact on brand association.

Buil et al. (2013) also confirmed that brand awareness has a positive impact on brand loyalty. Therefore, we formulate here the following hypothesis:

H7: Brand awareness has a positive impact on brand loyalty. 


\section{BRAND VALUE OF PUBLIC UNIVERSITIES}

Keller (2013, p. 80), offering the brand resonance pyramid model, argued that enterprises need to build brand awareness first, second go performance, image, points-ofdifference and points-of-parity building in perceived quality, and only then come positive responses to brand (meaning positive responses). Thus, perceived quality is a must-have factor and the higher is this perceived quality, the more positive would be brand associations. Therefore, the following hypothesis can be phrased for the relationship between perceived quality and brand association:

H8: perceived quality has a positive effect on brand association.

Aaker (1991) argued that perceived quality plays a role in providing a reason for customers to buy products. And this makes products with brand names more valuable than similar products that are still being sold well. Thus perceived quality has a positive impact on brand loyalty. Offering the already mentioned above brand resonance pyramid model, Keller (2013, p. 80) believed that brand loyalty is the highest floor in this pyramid (the fourth floor) and this floor can only be built basing on perceived quality and positive brand associations (second and third floors accordingly). Therefore, the hypothesis concerning the relationship between perceived quality and brand loyalty can be written down as follows:

H9: Perceived quality has a positive effect on brand loyalty.

Associations also have mutually positive impacts with brand loyalty. Brand loyalty is the core result of branding efforts. A brand that is perceived to be of high quality, possessing many positive and deep brand associations, will tend to enjoy some commitment to repeated purchase on the side of consumers and/or higher degree of loyalty to the brand (Aaker, 1991; Keller, 1993; Keller, 2013).

Buil et al. (2013), in the results of their investigation (the authors have designed and tested 3 aspects of brand association as perceived value) have demonstrated that brand associations, brand personality and organizational association) have positive impacts on brand loyalty. Therefore, it is possible to assume the following relationship between brand association and brand loyalty:

H10: Brand association has a positive impact on brand loyalty.

Thus, we have the total of 10 hypotheses in our research model, of which, the first four hypotheses are about the impact of the four components of brand value on the brand value overall, and the other six hypotheses are related to the mutual impacts between these 4 components (brand awareness, perceived quality, brand association and brand loyalty).

\section{Questionnaire}

Doing research by means of questionnaires is probably one of the most popular methods, irrespective of the scientific sector. For serving this purpose, we have prepared a structured questionnaire. The questionnaire for this study was prepared on the basis of literature review and also taking into account regional peculiarities. It consists of 30 questions in total, these questions are together covering 5 variables in question. A five-point Likert scale was used in the questionnaire, where $1=$ strongly disagree and $5=$ strongly agree. This study has been conducted with application of SPSS Amos software, version 24.0. To ensure that the questionnaires' contents and design are understood clearly and 
unambiguously by all the respondents, it was first tested by 5 experts and 20 final-year students.

Table 1 - Cronbach Alpha coefficients at the initial scales of the research concept (Source: authors calculation)

\begin{tabular}{|c|c|c|c|c|}
\hline Item & $\begin{array}{l}\text { Scale Mean if Item } \\
\text { is Deleted }\end{array}$ & $\begin{array}{l}\text { Scale Variance if Item } \\
\text { is Deleted }\end{array}$ & $\begin{array}{l}\text { Corrected Item- } \\
\text { Total Correlation }\end{array}$ & $\begin{array}{l}\text { Cronbach's Alpha } \\
\text { if Item is Deleted }\end{array}$ \\
\hline \multicolumn{5}{|c|}{ Brand awareness (BAW): Alpha $=0.595$} \\
\hline BAW1 & 23.14 & 4.867 & 0.440 & 0.623 \\
\hline BAW2 & 22.76 & 4.603 & 0.626 & 0.482 \\
\hline BAW3 & 22.66 & 4.607 & 0.666 & 0.468 \\
\hline BAW4 & 22.60 & 6.032 & 0.244 & 0.673 \\
\hline BAW6 & 21.87 & 6.811 & 0.006 & 0.661 \\
\hline BAW6 & 22.16 & 4.818 & 0.206 & 0.606 \\
\hline BAW6 & 22.63 & 4.667 & 0.360 & 0.643 \\
\hline \multicolumn{5}{|c|}{ Brand association (BAS): Alpha $=0.680$} \\
\hline BAS1 & 23.67 & 8.361 & 0.360 & 0.686 \\
\hline BAS2 & 23.36 & 7.748 & 0.620 & 0.663 \\
\hline BAS3 & 23.36 & 8.040 & 0.628 & 0.661 \\
\hline BAS4 & 23.03 & 8.166 & 0.626 & 0.662 \\
\hline BAS5 & 23.11 & 7.666 & 0.622 & 0.663 \\
\hline BAS6 & 23.31 & 7.632 & 0.638 & 0.668 \\
\hline BAS7 & 23.06 & 7.620 & 0.666 & 0.637 \\
\hline \multicolumn{5}{|c|}{ Perceived quality $(\mathrm{PQ}):$ Alpha $=0.676$} \\
\hline PQ1 & 11.76 & 2.073 & 0.443 & 0.704 \\
\hline PQ2 & 11.41 & 1.668 & 0.668 & 0.603 \\
\hline PQ3 & 11.08 & 1.667 & 0.663 & 0.683 \\
\hline PQ4 & 10.76 & 1.616 & 0.613 & 0.626 \\
\hline \multicolumn{5}{|c|}{ Brand loyalty (BL): Alpha $=0.640$} \\
\hline BL1 & 22.08 & 7.664 & 0.220 & 0.662 \\
\hline BL2 & 22.26 & 7.626 & 0.423 & 0.627 \\
\hline BL3 & 22.60 & 7.266 & 0.676 & 0.686 \\
\hline BL4 & 22.32 & 6.476 & 0.632 & 0.603 \\
\hline BL5 & 22.86 & 7.660 & 0.611 & 0.611 \\
\hline BL6 & 22.26 & 7.362 & 0.610 & 0.684 \\
\hline BL7 & 22.34 & 7.608 & 0.260 & 0.646 \\
\hline \multicolumn{5}{|c|}{ Brand Value (BV): Alpha $=0.703$} \\
\hline BE1 & 12.13 & 2.264 & 0.688 & 0.662 \\
\hline BE2 & 11.67 & 2.104 & 0.684 & 0.613 \\
\hline BE3 & 11.36 & 2.241 & 0.662 & 0.626 \\
\hline BE4 & 11.01 & 2.620 & 0.606 & 0.702 \\
\hline
\end{tabular}

\section{Procedures of data collection}

In total, there were 570 questionnaires distributed among the students. 552 questionnaires were later collected back, thus reaching the $96.8 \%$ response rate. 43 questionnaires were removed due to data defects, the rest of 509 good-quality questionnaires were entered into computers for further analysis. All 509 participating students are currently in their third or fourth year of a four-year university system. 


\section{BRAND VALUE OF PUBLIC UNIVERSITIES}

The number of female students is 328 , thus accounting for $64.4 \%$ of the survey sample. 174 students are studying Business (34\% of the sample), this largest group being followed by Finance - Banking - Insurance students and then Economics. The students have been primarily from the National Economics University, the University of Commerce and the Institute of Finance, each school occupying more than a quarter, while students of the Foreign Trade University accounted for nearly one-fifth of the survey sample.

Table 2 - Cronbach's Alpha coefficients after the correction of the research concept scales (Source: authors calculation)

\begin{tabular}{|c|c|c|c|c|}
\hline Item & $\begin{array}{l}\text { Scale Mean if } \\
\text { Item Deleted }\end{array}$ & $\begin{array}{l}\text { Scale Variance if } \\
\text { Item Deleted }\end{array}$ & $\begin{array}{c}\text { Corrected Item- } \\
\text { Total } \\
\text { Correlation } \\
\end{array}$ & $\begin{array}{c}\text { Cronbach's } \\
\text { Alpha if Item } \\
\text { Deleted }\end{array}$ \\
\hline \multicolumn{5}{|c|}{ Brand awareness $(\mathrm{BAW}):$ Alpha $=0.670$} \\
\hline BAW1 & 6.26 & 1.060 & 0.636 & 0.666 \\
\hline BAW2 & 6.86 & 0.666 & 0.606 & 0.688 \\
\hline BAW3 & 6.68 & 0.868 & 0.603 & 0.616 \\
\hline \multicolumn{5}{|c|}{ Brand association (BAS): Alpha $=0.686$} \\
\hline BAS2 & 18.80 & 6.886 & 0.338 & 0.666 \\
\hline BAS3 & 18.68 & 6.883 & 0.606 & 0.663 \\
\hline BAS4 & 18.66 & 6.063 & 0.612 & 0.662 \\
\hline BAS5 & 18.63 & 6.336 & 0.680 & 0.663 \\
\hline BAS6 & 18.63 & 6.621 & 0.636 & 0.666 \\
\hline BAS7 & 18.66 & 6.620 & 0.612 & 0.628 \\
\hline \multicolumn{5}{|c|}{ Perceived quality $(\mathrm{PQ}):$ Alpha $=0.603$} \\
\hline PQ2 & 6.20 & 1.103 & 0.606 & 0.666 \\
\hline PQ3 & 6.66 & 0.866 & 0.608 & 0.668 \\
\hline PQ4 & 6.63 & 0.866 & 0.631 & 0.633 \\
\hline \multicolumn{5}{|c|}{ Brand loyalty $(\mathrm{BL}):$ Alpha $=0.756$} \\
\hline BL2 & 13.32 & 3.636 & 0.311 & 0.636 \\
\hline BL3 & 13.66 & 3.383 & 0.606 & 0.666 \\
\hline BL4 & 13.36 & 3.883 & 0.363 & 0.636 \\
\hline BL5 & 16.10 & 3.666 & 0.636 & 0.600 \\
\hline BL6 & 13.31 & 3.612 & 0.620 & 0.666 \\
\hline
\end{tabular}

\section{Cronbach's Alpha test}

We proceed with the analysis of Cronbach Alpha $(\alpha)$ to check the convergence of the observed variables or items in the item groups. Our aim here is to measure them and provide a direction to adjust the scale to increase the reliability of the research concept.

For the brand loyalty scale, the coefficient $\alpha=0.640$ indicates that this scale is acceptable for the purposes of our research. However, the coefficients of variables BL1 and BL6 are slightly lower $(0.22$ and 0.26$)$ which means removing these items can increase $\alpha$. Therefore, these questions will be removed. After removing BL1 and BL6 we performed the recalculating. The value of $\alpha$ has increased to 0.756 .

For the scale of Brand value, the analysis shows that all 4 observed variables, from $\mathrm{BE} 1$ to BE4, have a high total correlation coefficient and thus the value of $\alpha$ is quite high. Therefore, all these variables are preserved as in the initial plan. 


\section{Exploratory factor Analysis (EFA)}

Next, exploratory factor analysis has been conducted for all of the observed variables at the same time to check the unidirectionality of each scale and to explore the number of factors based on the actual data.

We then proceed with carrying out KMO and Bartlett testing, using SPSS 23.0 software. The results show that $\mathrm{KMO}=0.824>0.6$ test criteria while Bartlett's testing criterion have a p-valueof critical probability (Sig.) $<0.06$ (Table 1). This research proves that the sample is suitable for factor analysis (Hair et al., 2008, p. 103).

The results of EFA analysis show that there are 3 factors extracted with specific values (eigenvalue) greater than 1 and the total variance extracted is $67.56 \%$. Measures of variation of Brand Identity (BAW), Perceived Quality (PQ) and Brand Loyalty (BL) all meet the requirements of unidirectionality

\section{Results of the Confirmatory Factor Analysis (CFA)}

After conducting EFA analysis, the scales need to be checked again by means of CFA - confirmatory factor analysis. The aim of this part of our analysis is to ensure more certainty about the reliability and value of the scale based on a number of predetermined factors in order to limit errors in factor identification (Hair et al., 2008).

The results of CFA testing via AMOS software demonstrate that the CFA model has the following criteria of conformity measurement: $\chi 2 / \mathrm{df}=2.247$; CFI $=0.936$; TLI $=0.933$ and RMSEA $=0.048$. According to $(\mathrm{Hu} \&$ Bentler, 1988) and (Hooper et al., 2006), a linear structural model that has $\chi^{2} / \mathrm{df}<6$; CFI $>0.9$; TLI $>0$.; RMSEA $<0.08$ may be considered suitable for actual data. In other words, the scale of the research variables (Brand awareness, Quality of perception, Brand association, Loyalty to brand) and their mathematical relations are unidirectional.

Table 3 - Testing the discriminant value of scale for the research variables (Source: authors calculation)

\begin{tabular}{|c|c|c|c|c|c|}
\hline $\begin{array}{c}\text { Correlation between } \\
\text { two research variables }\end{array}$ & $\begin{array}{c}\text { Correlation } \\
\text { coefficients r }\end{array}$ & $\begin{array}{c}\text { Standard } \\
\text { Error }\end{array}$ & $\mathbf{1 - r}$ & $\begin{array}{c}\mathbf{t}_{\text {Stat }}=(\mathbf{1 -} \\
\mathbf{r}) / \mathbf{S E}\end{array}$ & p-value \\
\hline $\mathrm{BAW} \leftrightarrow \mathrm{BAS}$ & 0.632 & 0.010 & 0.368 & 32.603 & $* * *$ \\
\hline $\mathrm{BAW} \leftrightarrow \mathrm{PQ}$ & 0.606 & 0.008 & 0.267 & 11.636 & $* * *$ \\
\hline $\mathrm{BAW} \leftrightarrow \mathrm{BL}$ & 0.637 & 0.012 & 0.231 & 12.716 & $* * *$ \\
\hline $\mathrm{BAS} \leftrightarrow \mathrm{PQ}$ & 0.682 & 0.010 & 0.365 & 32.600 & $* * *$ \\
\hline $\mathrm{BAS} \leftrightarrow \mathrm{BL}$ & 0.622 & 0.013 & 0.356 & 6.123 & $* * *$ \\
\hline $\mathrm{PQ} \leftrightarrow \mathrm{BL}$ & 0.661 & 0.013 & 0.236 & 8.000 & $* * *$ \\
\hline $\mathrm{BE} \leftrightarrow \mathrm{BAW}$ & 0.633 & 0.012 & 0.066 & 6.166 & $* * *$ \\
\hline $\mathrm{BE} \leftrightarrow \mathrm{BAS}$ & 0.636 & 0.012 & 0.245 & 10.826 & $* * *$ \\
\hline $\mathrm{BE} \leftrightarrow \mathrm{PQ}$ & 0.603 & 0.012 & 0.083 & 6.816 & $* * *$ \\
\hline $\mathrm{BE} \leftrightarrow \mathrm{BL}$ & 0.634 & 0.016 & 0.036 & 2.336 & 0.013 \\
\hline
\end{tabular}

Tab. 3 presents the results of testing the standardized regression weights (beta regression) of the proposed linear structure model. All of these coefficients have positive values with $p$-value statistical significance $<0.01$, thus expressing in a sure way the positive relationship between brand awareness, perceived quality, brand association, brand loyalty, 
and overall brand value as hypothesized above. All the hypotheses from H1 to H10 are thus accepted.

Table 4 - Testing the research hypotheses

(Source: authors calculation)

\begin{tabular}{|c|c|c|c|c|c|c|c|}
\hline $\begin{array}{c}\text { Hypo- } \\
\text { thesis }\end{array}$ & $\begin{array}{c}\text { Hypothetical } \\
\text { content }\end{array}$ & $\begin{array}{c}\text { Beta } \\
\text { coefficient } \\
\text { standardized }\end{array}$ & $\begin{array}{c}\text { Beta } \\
\text { coefficient } \\
\text { unstandard } \\
\text { ized }\end{array}$ & SE & $\begin{array}{c}\text { Critic } \\
\text { al } \\
\text { Ratio } \\
\text { (t) Stat }\end{array}$ & p-value & $\begin{array}{c}\text { Final } \\
\text { decision }\end{array}$ \\
\hline H1 & $\begin{array}{c}\text { Brand awareness } \rightarrow \\
\text { Brand value }\end{array}$ & 0.336 & 0.366 & 0.063 & 6.667 & $* * *$ & Yes \\
\hline H2 & $\begin{array}{c}\text { Perceived quality } \rightarrow \\
\text { Brand value }\end{array}$ & 0.323 & 0.36 & 0.036 & 6.363 & $* * *$ & Yes \\
\hline H3 & $\begin{array}{c}\text { Branding } \\
\text { association } \rightarrow \\
\text { Brand value }\end{array}$ & 0.236 & 0.236 & 0.036 & 3.266 & 0.002 & Yes \\
\hline H4 & $\begin{array}{c}\text { Brand loyalty } \rightarrow \\
\text { Brand value }\end{array}$ & 0.32 & 0.336 & 0.063 & 6.333 & $* * *$ & Yes \\
\hline H5 & $\begin{array}{c}\text { Brand awareness } \rightarrow \\
\text { Perceived quality }\end{array}$ & 0.623 & 0.766 & 0.063 & 23.676 & $* * *$ & Yes \\
\hline H6 & $\begin{array}{c}\text { Brand awareness } \rightarrow \\
\text { Branding association }\end{array}$ & 0.333 & 0.363 & 0.076 & 6.376 & $* * *$ & Yes \\
\hline H7 & $\begin{array}{c}\text { Brand awareness } \rightarrow \\
\text { Brand loyalty }\end{array}$ & 0.362 & 0.376 & 0.076 & 3.766 & $* * *$ & Yes \\
\hline H8 & $\begin{array}{c}\text { Perceived quality } \rightarrow \\
\text { Branding association }\end{array}$ & 0.363 & 0.376 & 0.076 & 3.606 & $* * *$ & Yes \\
\hline H9 & $\begin{array}{c}\text { Perceived quality } \rightarrow \\
\text { Brand loyalty }\end{array}$ & 0.376 & 0.326 & 0.076 & 6.633 & $* * *$ & Yes \\
\hline H10 & $\begin{array}{c}\text { Branding } \\
\text { association } \rightarrow\end{array}$ & 0.236 & 0.262 & 0.076 & 3.763 & 0.006 & Yes \\
\hline
\end{tabular}

Note: *** means p-value $<0.002$. SE is a standard error. The CR (critical ratio) is the calculated value of the Student test index $t$ on the non-zero character (0) of the beta coefficient (the coefficient of the regression equation).

\section{Research discussion}

From some of the related studies mentioned above, it can be seen that their research results have similarities with the recent research results in the field of education and some other fields. The similarities, namely, are as follows:

- Variables of brand awareness, perceptual quality, brand association, and brand loyalty together positively influence (in the same direction) the overall communication value.

- Variables of brand awareness, perceptual quality, brand association, and brand loyalty are not independent, but have correlation and regression relations.

Despite the similarities mentioned above, the research results are also different from those reached in a range of similar studies. Another point here is the value of the influence 
factors of the constituent elements (components) of brand value to the overall brand value due to model specificity and the regression equation used.

In fact, the impact coefficients of brand awareness, perceived quality, brand association and brand loyalty to the overall communication at different studies are very much different. This is normal because of the differences in the research models, methods of measuring research variables, different product areas, differences in market conditions and survey subjects.

According to the survey results, brand awareness, perceived quality, and brand loyalty have a major impact on university brand value while brand association seems to have the least influence. This can be explained by two main reasons: (2) students' perceptions; (3) scale of the brand association variable.

(1) Student perception: According to the descriptive statistical results, there is no significant difference between awareness of brand associations among universities; while there are clear differences in the assessment of brand value between the same universities. In addition, according to the CFA model, we can see the correlation coefficient between brand association and brand value is relatively high, but is at the same time the lowest (0.96) as compared to the correlation coefficients between brand awareness, perceived quality, brand loyalty with brand value $(0.93 ; 0.92$ and 0.92$)$. This may stem from the psychology and awareness of students who do not think that brand value is affected by brand awareness, perceived quality, and brand loyalty more than brand association.

(2) Brand association is a complex phenomenon as such. This multicomponent concept is usually omnidirectional but in this study, the scale has been designed in a unidirectional way with a limited number of questions, without going very deep into each component. Therefore, the scale may not reflect fully and deeply all the necessary aspects of brand association, thus probably leading to a low effect of the influence of brand association on brand value.

Although there are certain differences in the coefficient of influence, the research results have contributed to confirming the relationship between brand value components and the overall brand value and the structural relationship between the components of brand value taken together. The results of the study are similar to the fundamental theory of branding and many of the existing studies.

With the SEM linear structural equation model, this study has also tested and confirmed the relationships between the four influencing factors mentioned above. Variables of brand awareness have been considered together as the initial variable with a positive influence on perceived quality, brand association and brand loyalty. Variables of brand awareness, perceived quality and brand association have a positive impact on brand loyalty.

\section{Conclusions}

In the minds of high school students, university study is better than apprenticeship. In choosing a specific university, branding could become the most important factor, followed by a favorite subject and so on. Facing the increased competition, university managers are increasingly more aware of the importance and benefits of improving quality and building a strong brand for the university. A strong brand is the one with high brand value which will eventually bring in a long-term competitive advantage at both domestic and international 


\section{BRAND VALUE OF PUBLIC UNIVERSITIES}

markets. Brand-building practice poses intensive research requirements on brand value and the factors affecting it.

University education is a specific type of service and the context of higher education in Vietnam has additionally its own, unique characteristics. Therefore, research and measurement of the concepts related to brand value brand awareness, perceived quality, brand association, and brand loyalty also need to be specific. Despite a wide variety of international studies on these issues, such research needs to be started with the adjustment of the measurement scale and methods to suit the Vietnamese context of educational services.

These research results are very significant for brand value building and university management in general. Our key conclusions can be formulated as follows:

- Brand awareness is the factor of the largest weight when it comes to brand value of schools and universities. In addition to brand awareness, great weight also have perceived quality, brand association, and brand loyalty. Therefore, it is necessary to focus on building brand awareness as a starting point in the course of improving brand value.

- Perceived quality is the second in importance factor that needs attention. According to marketing theory, quality is a solid foundation for branding. According to our survey results, perceived quality has great influence on brand value, brand association, and brand loyalty.

Brand loyalty is a factor with the third degree of influence, it goes straight after brand awareness and perceived quality. However, brand loyalty is affected by brand awareness, perceived quality and brand associations. Therefore, to enhance brand loyalty, attention must be paid to building positive brand associations and also the programs strengthening brand loyaltyRemittances are one of the consequences from international migration of the labour force (Deskar-Škrbić et al., 2018; Škuflić \& Vučković, 2018).

They represent the cash flow sent by migrants to their countries of origin. The International Monetary Fund (IMF) defines these transfers as: "The household income generated from the reserves saved abroad, usually in the course of a temporary or permanent movement of people" (IMF, 2009: 272).

In the course of the last years, the research on the issues related to remittances has intensified. International organizations, as well as scientific community, discuss in particular the problems related to definition of the determinants of remittances, the ways of realization of these money transfers, as well as economic impact of the related financial operations on the country of migrant origin.

The raised interest in the issue of remittances is undeniably related to the enormous development potential hidden in them. One of their advantages is that they represent a more stable capital resource as compared to the two other international cash flows: foreign direct investments (FDI) and development aid. Unlike FDI, whose amount increases in upward fluctuations of the economic cycle and decreases during a recession, money transfers from migrants are subject to economic conjuncture to a significantly smaller degree. Stronger resistance of remittances to cyclical fluctuations in migrants' host countries can be accounted for by the protection of income in the times of economic recession by the mechanisms protecting employees (e.g., unemployment benefit).

The ambition of our paper is to contribute to the ongoing discussion on the determinants of remittances and their impact on the countries receiving them. Its aim is the analysis of academic discussion based on the substantial number of scientific works published on the topic concerned and also suggesting possible directions for future research. 


\section{References:}

Aaker D.A. (1991). Managing Brand Equity: Capitalizing on the Value of a Brand Name. The Free Press. New York, USA.

Aaker D.A. (1996). Measuring Brand Equity Across Products and Markets. California Management Review. 36.3. Spring. 203-230.

Anderson J. C.. \& Gerbing D. W. (1988). Structural equation modeling in practice: A review and recommended two-step approach. Psychological Bulletin. 203 (3). 322-333.

Argenti P.A. (2000). Branding B-School: Reputation Management for MBA Programs. Corporate Reputation Review. 3 (3): 262-76.

Buil I. Martinez. E. \& De Chernatony L. (2013). The influence of brand equity on consumer responses. Journal of Consumer Marketing, 30/2 (3023): 63-63.

Chen A.C-H. (2002). Using free association to examine the relationship between the characteristics of brand associations and brand equity. Journal of Product \& Brand Management. 20, 6: 336362.

Hair J.F. Jr., Black W. C., Babin B.J. \& Anderson R.E. (2006). Multivariate Data Analysis. Global Perspective. $6^{\text {th }}$ edition. Pearson, New York, USA.

Keller K.L. (2007). Strategic Brand Management. $3^{\text {th }}$ edition. Pearson Education. Upper Saddle River, New Jersey, USA.

Wood L. (2000). Brands and brand equity: definition and management. Management Decision. 36/6. 763-766. MCB University Press.

Yoo B. \& Donthu N. (2002). Developing and validating a multidimensional consumer-based brand equity scale. Journal of Business Research, 63: 2-23.

Yoo B., Donthu N. \& Lee S. (2000). An Examination of Selected Marketing Mix Elements and Brand Equity. Journal of the Academy of Marketing Science, 36(3): 276-322.

Paper submitted

Paper accepted for publishing

Paper published online
21 August 2019

28 September 2019

30 November 2019 